\title{
EDWARD SAID: UM PERFIL INTELECTUAL
}

\author{
Danilo Guiral Bassi ${ }^{1}$
}

Edward Wadie Said, talvez o mais célebre intelectual palestino, teve uma trajetória acadêmica e política marcada por um misto de polêmicas, divergências e admiração. Após sua morte, em decorrência de um câncer, Said recebeu diversas homenagens, nos mais diversos meios. Intelectuais e ativistas políticos se revezaram para lamentar a perda de "um dos maiores embaixadores dos povos oprimidos e injustiçados"2; de um intelectual "inspirador"3, "cortês e gracioso"4, "charmoso e articulado", "que diz[ia] mais do que os próprios cientistas"6; de um defensor da "justiça e da liberdade [...], cujo legado [...] será uma inspiração e um guia para os anos que virão"7, autor de uma "grande obra", que "criou uma disciplina que, de alguma forma, trouxe o humanismo para o centro do debate"8; de "um combatente da causa palestina"9 ou simplesmente de um "intelectual honesto."10

As críticas positivas à obra de Said não foram, todavia, uníssonas. Acerca de sua produção, foram escritas linhas mais duras, como as que alegam ter sido ele um "terrorista intelectual [...] incompetente para escrever o que pretendia"11, cuja obra "é uma versão fantasiosa da história"12, com um "legado pernicioso"13.

\footnotetext{
${ }^{1}$ Mestre em História Social pela Universidade de São Paulo.

${ }^{2}$ HABIB, Mohamed. "O Mundo sem Edward Said" in: CLEMESHA, Arlene (org.). Edward Said: Trabalho intelectual e crítica social. São Paulo: Editora Casa Amarela, 2005, p. 50.

${ }^{3}$ SILVA, Ligia Osorio. "Edward Said e o Imperialismo Cultural". In: CLEMESHA, A. (org.), op. cit., p. 26.

${ }^{4}$ STROUSE, Jean. In: COLUMBIA University. Remembering Edward W. Said: November 1, 1935 - September 25, 2003. Nova Iorque: Columbia University, 2004, p. 100.

${ }^{5}$ KHALIDI, Rashid. In: ibidem, p. 59.

${ }^{6}$ AB'SABER, Aziz. "(Re)aprendendo a enxergar o colonialismo". In: CLEMESHA, A. (org.), op. cit., p. 35.

${ }^{7}$ CHOMSKY, Noam. In: COLUMBIA University, op. cit., p. 22.

${ }^{8}$ FONER, Eric. In: ibidem, p. 41.

${ }^{9}$ ANTUNES, Ricardo. "Edward Said: um libelo contra a barbárie”. In: CLEMESHA, A. (org.), op. cit., p. 23.

${ }^{10}$ ARBEX JR., José. "Um Exemplo de Honestidade Intelectual”. In: ibidem, p. 20.

${ }^{11}$ WARRAQ, Ibn. Debunking Edward Said. Disponível em: <http://www.butterfliesandwheels.org/ 2003/debunking-edward-said/>. Acesso em 14 ago. 2015

${ }^{12}$ IRWIN, Robert. Pelo Amor ao Saber: os Orientalistas e seus Inimigos. Rio de Janeiro: Editora Record, 2006, p. 331.

${ }^{13}$ WARRAQ I., op. cit.
} 
A partir dessa divergência na recepção da obra de Edward Said, podemos nos permitir a colocação de algumas perguntas: quem foi Edward Said? Quais foram suas ideias centrais, sobretudo acerca da análise do orientalismo? Qual foi sua influência sobre a produção científica desde a publicação de suas primeiras obras de grande repercussão? Quais críticas foram feitas à sua obra? As críticas são verdadeiras e, ainda que fundamentadas, invalidam a essência de suas teorias?

Para responder a estas perguntas, vamos, num primeiro momento, traçar uma breve biografia de Edward Said e expor seu ponto de vista sobre o papel a ser desempenhado pelo intelectual para, em seguida, analisar sua teoria acerca do orientalismo; abordaremos, na sequência, algumas de suas ideias no que diz respeito à questão palestina para, finalmente, explicitar alguns debates em que Said se envolveu e as críticas que foram feitas à sua obra e, assim, tentar formular algumas conclusões finais.

\section{Biografia, obra e engajamento}

Edward Said nasce em 1935 na cidade de Jerusalém, então sob mandato britânico da Liga das Nações. Seu pai havia migrado aos 16 anos para os Estados Unidos para fugir da convocação pelas forças armadas do Império Otomano em guerra contra a Bulgária; durante a Primeira Guerra mundial, luta como soldado norte-americano na França e depois retorna à Palestina, onde forma família. Com a eclosão da primeira guerra árabeisraelense, a família de Said deixa Jerusalém e se instala no Cairo. Após pouco tempo em um colégio inglês conservador, Said é enviado pela família para os Estados Unidos, onde conclui seus estudos básicos e inicia uma carreira acadêmica impressionante, passando pelas prestigiosas universidades de Princeton, Harvard, Johns Hopkins, Yale e Columbia, onde passa a lecionar literatura a partir de $1963^{14}$.

Além de professor universitário, Edward Said foi membro da Academia NorteAmericana de Artes e de Ciências e da Sociedade Norte-Americana de Filosofia e presidente da Associação de Línguas Modernas. Em 1966, inicia, com um livro sobre Joseph Conrad, sua profícua produção bibliográfica.

No ano seguinte, a partir da Guerra dos Seis Dias, Said passa a demonstrar maior interesse pela política e, sobretudo, pelas questões de sua terra de origem: a Palestina ${ }^{15}$. Torna-se membro da Conferência Nacional Palestina, espécie de parlamento palestino no exílio, onde permanece por 14 anos, até seu rompimento com a Autoridade Nacional Palestina de Yasser Arafat, em decorrência de seu desacordo com a forma como estavam sendo guiadas as negociações de paz entre palestinos e israelenses.

Seus textos serão intercalados entre si, entre análises sobre Joseph Conrad e música clássica, entre debates políticos e teoria literária, entre estudos sobre Vico e

\footnotetext{
${ }^{14}$ SAID, Edward W. Fora do Lugar: Memórias. São Paulo: Companhia das Letras, 2004.

${ }^{15}$ Idem.
} 


\section{perfil intelectual}

propostas de solução para o conflito israelo-palestino. Suas ideias estão presentes em artigos de periódicos tão variados quanto The Nation, The Guardian, London Review of Books, Le Monde Diplomatique, Counterpunch, Al Ahram e al-Hayat e em seus livros, entre os quais podemos citar Beginnings, A Questão da Palestina, Cobrindo o Islã, A Política da Expropriação, A Paz e seus Dissidentes, O Fim do Processo de Paz, Cultura e Resistência, Paralelos e Paradoxos, Representações do Intelectual, Humanismo e Crítica Democrática e Freud e os Não-Europeus. Mas sua obra magna ainda continua sendo aquela publicada pela primeira vez em 1978, Orientalismo: o Oriente como invenção do Ocidente, e seu desdobramento teórico, Cultura e Imperialismo, de 1983.

Edward Said morre em 2003, após 12 anos de tratamento de uma leucemia linfoide crônica, aos 67 anos de idade, na cidade de Nova Iorque, onde já morava havia décadas.

Apesar de sua morte, sua obra deixou seguidores, sobretudo nos meios acadêmicos, ao ponto de alguns considerarem que os saidianos se tornaram hegemônicos em determinadas áreas de estudo ${ }^{16}$. Influenciado por autores pós-modernos (notadamente Michel Foucault ${ }^{17}$, no que diz respeito à análise do discurso ${ }^{18}$ e das relações entre saber e poder ${ }^{19}$ ), Edward Said tem sua obra enquadrada como marco da literatura crítica póscolonial. Nela, ele teve a oportunidade de desenhar aquele que ele considera o papel do intelectual na sociedade, dedicando um livro inteiro à busca deste objetivo ${ }^{20}$.

Edward Said se definia como um humanista, no sentido de um intelectual multifacetado, que, no seu caso, valorizou o estudo da arte e a crítica literária, mas sempre mantendo um amplo interesse pelos demais aspectos do saber, do conhecimento e da arte ${ }^{21}$, com a incumbência de quebrar estereótipos e reducionismos ${ }^{22}$, de apresentar "modelos alternativos aos modelos redutivamente simplificadores e aos modelos restritivos baseados na hostilidade mútua" ${ }^{23}$. Said se colocava igualmente como um intelectual no exílio, marcado pela sensação constante de deslocamento e de estar sempre "fora do lugar" (expressão que daria nome a suas memórias ${ }^{24}$ ) e que, por essa posição peculiar, dizia ele, não aceitava o discurso comum, a tradição e a língua comum do patriotismo ou

\footnotetext{
${ }^{16}$ TEITELBAUM, Joshua; LITVAK, Meir. "Students, teachers, and Edward Said: taking stock of Orientalism" in: The Middle East Review of International Affairs, v. 10, n. 2, mar. 2006. Disponível em: <http://www.rubincenter.org/2006/03/teitelbaum-and-litvak-2006-03-02/>. Acesso em: 15 ago. 2015

${ }^{17}$ SAID, Edward W. "Foucault e a imaginação do poder". In: Reflexões sobre o exílio e outros ensaios. São Paulo: Companhia das Letras, 2003, p. 93-99.

${ }^{18}$ SAID, Edward W. Orientalismo: o Oriente como invenção do Ocidente. São Paulo: Companhia das Letras, 2007, p. 29-30, 142, 187.

${ }^{19}$ Ibidem, p. 53-54, 173.

${ }^{20}$ SAID, Edward W. Representations of the Intellectual. Nova Iorque: Vintage Books, 1996.

${ }^{21}$ SADER, Emir. "Introdução: Edward Said - uma pequena homenagem”. In: CLEMESHA, A. (org.), op. cit., p. 14.

${ }^{22}$ SAID, Edward W. Representations of the Intellectual. Nova Iorque: Vintage Books, 1996, p. XI.

${ }^{23}$ SAID, Edward W. Orientalismo: o Oriente como invenção do Ocidente. São Paulo: Companhia das Letras, 2007 , p. 20

${ }^{24}$ SAID, Edward W. Fora do Lugar: Memórias. São Paulo: Companhia das Letras, 2004.
} 


\section{perfil intelectual}

da mídia ${ }^{25}$. Em Representações do Intelectual, Said aprofunda sua crítica à especialização do conhecimento e das ciências (crítica esta já presente em Orientalismo, onde ele declara que "o argumento do especialista pode funcionar com muita eficácia para bloquear a perspectiva mais ampla e [...] mais séria em termos intelectuais"26). Diz ele:

A especialização implica perder de vista o esforço árduo de construir arte e conhecimento e significa com frequência fechar a porta à história, à música ou à política. A pressão do profissionalismo, exercida sobre os que a ele aderem, é a tendência para o poder e a autoridade, para as exigências e prerrogativas do poder e para se ser diretamente usado por ele. ${ }^{27}$

A influência que autores como Antonio Gramsci ${ }^{28}$, Theodor Adorno e Jean-Paul Sartre $^{29}$ tiveram sobre Said na construção da defesa do intelectual-ativista é explicitada por ele próprio: para Said, a produção intelectual não estava dissociada da política e o intelectual não poderia se furtar a essa relação e - mais do que isso - ele deveria se abrir à sociedade:

[...] o intelectual não representa um ícone do tipo estátua, mas uma vocação individual, uma energia, uma força obstinada, abordando com uma voz empenhada e reconhecível na linguagem e na sociedade uma porção de questões, todas elas relacionadas, no fim das contas, com uma combinação de esclarecimentos e emancipação ou liberdade. ${ }^{30}$

Uma definição dada por Said sobre o papel do intelectual elucida o elo que ele buscou entre produção de conhecimento, engajamento político-social do intelectual e suas teorias que abordaremos no próximo ponto:

O papel do intelectual, de um modo geral, é elucidar a disputa, desafiar e derrotar tanto o silêncio imposto quanto o silêncio conformado do poder invisível, em todo lugar e momento que seja. Pois há uma equivalência social e intelectual entre essa massa de interesses esmagadores e o discurso usado para justificar, escamotear e mistificar seu funcionamento enquanto, simultaneamente, previne contra objeções e desafios que possam surgir contra ele. ${ }^{31}$

\footnotetext{
${ }^{25}$ FARAH, Paulo Daniel. “Colóquio e contraponto". In: CLEMESHA, A. (org.), op. cit., p. 71.

${ }^{26}$ SAID, Edward W. Orientalismo: o Oriente como invenção do Ocidente. São Paulo: Companhia das Letras, 2007, p. 42-43.

${ }^{27}$ SAID, Edward W. Representações do Intelectual - as Conferências Reith de 1993. apud: HATOUM, Milton. "Edward Said e os Intelectuais". In: CLEMESHA, A. (org.), op. cit., p. 32.

${ }^{28}$ SAID, Edward W. Orientalismo: o Oriente como invenção do Ocidente. São Paulo: Companhia das Letras, 2007, p. 34, 56-57.

${ }^{29}$ SAID, Edward W. "Meu encontro com Sartre". In: Cultura e Política. São Paulo: Boitempo Editorial, 2003, p. 20-28.

${ }^{30}$ SAID, Edward W. Representações do Intelectual - as Conferências Reith de 1993, p.78 apud HATOUM, M., op. cit., p. 33.

${ }^{31}$ SAID, Edward W. Cultura e Imperialismo. São Paulo: Companhia das Letras, 1995, p. 33.
} 


\section{Orientalismo: discurso e imperialismo}

"O Oriente não é um fato inerte da natureza"32, é uma criação humana, fruto de uma divisão imaginativa entre Leste e $0_{e s t e}^{33}$ : eis o pressuposto da mais célebre obra de Edward Said, Orientalismo: o Oriente como invenção do Ocidente. Adotando a noção de discurso produzido pelo poder como forma de controle e dominação de Michel Foucault, Said busca, nessa obra, construir a ideia do orientalismo não apenas como área de especialidade do conhecimento, mas como discurso, como uma rede de interesses que liga a produção de conhecimento à capacidade de dominação ${ }^{34}$.

O orientalismo, que se apresenta apenas como uma área do conhecimento (abarcando o conjunto dos estudos sobre o Oriente, mais especificamente sobre o Oriente Médio, incluindo os de língua e cultura árabe), serviria como berço do imaginário de “um arranjo complexo de ideias 'orientais' (o despotismo oriental, o esplendor oriental, a crueldade, a sensualidade)"35, em que o conhecimento sobre o Oriente é gerado pela força e pela dominação, onde o oriental passa a ser "contido e representado por estruturas dominadoras" 36 . 0 orientalismo se construiria, dessa forma, como um "conjunto de sonhos, imagens e vocabulários" acerca do Outro ${ }^{37}$. Ao invés de desmontar imagens distorcidas e preconceitos existentes, o orientalismo teria servido (e serviria ainda no presente) para perpetuá-los.

0 Oriente, "vivenciado pelos ocidentais por lentes europeias" ${ }^{38}$, precisaria ser "orientalizado"39, enquadrado nos próprios pressupostos interessados daqueles que ao mesmo tempo o descrevem e o dominam (ou buscam dominar), ou seja, pelos orientalistas, que buscam "confirmar o Oriente, não desestabilizar convicções já firmes"40 sobre este. Segundo Said, o orientalismo apresenta determinadas características, entre elas "uma tendência a dividir, subdividir e tornar a dividir o seu tema, sem jamais mudar de opinião sobre o Oriente ser sempre o mesmo objeto imutável, uniforme e radicalmente peculiar"41.

Isso não significa reduzir, como diz o próprio Said, o orientalismo a "uma simples coletânea de mentiras" ${ }^{42}$, mas sim reconhecer que "a relação entre o Ocidente e o Oriente

\footnotetext{
${ }^{32}$ SAID, Edward W. Orientalismo: o Oriente como invenção do Ocidente. São Paulo: Companhia das Letras, 2007, p. 31.

${ }^{33}$ Ibidem, p. 274.

${ }^{34}$ Ibidem, p. 29-30

${ }^{35}$ Ibidem, p. 30

${ }^{36}$ Ibidem, p. 73-74.

${ }^{37}$ Ibidem, p. 115.

${ }^{38}$ Ibidem, p. 96.

${ }^{39}$ Ibidem, p. 155.

${ }^{40}$ Ibidem, p. 105.

${ }^{41}$ Ibidem, p. 147.

${ }^{42}$ Ibidem, p. 33.
} 


\section{perfil intelectual}

é uma relação de poder, de dominação, de graus variáveis de uma hegemonia complexa"43, "um intercâmbio dinâmico entre autores individuais e os grandes interesses políticos modelados pelos três grandes impérios - o britânico, o francês, o americano - em cujo território intelectual e imaginativo a escrita foi produzida" 44 e que partilham e constroem este "arquivo de informações"45. Corporações, fundações, companhias petrolíferas, missões religiosas, grupos militares, serviços de relações exteriores e de inteligência estariam, assim, intimamente ligados ao mundo acadêmico em busca da afirmação e da persistência dos dogmas orientalistas, ou seja, da imagem criada no discurso acerca do Oriente Médio, dos árabes e dos muçulmanos ${ }^{46}$.

Sob o argumento de que "a sociedade e a cultura literária só podem ser compreendidas e estudadas em conjunto" ${ }^{47}$, Said busca, em seu livro, comprovar a existência de uma correlação entre produção literária, estudos orientalistas e dominação ocidental sobre o Oriente Médio através da análise de textos literários, de textos políticos e das artes plásticas, englobando em sua análise autores tão diversos quanto Arthur James Balfour, Flaubert, Lorde Cromer, Byron, Chateaubriand, Goethe, Henry Kissinger, Lamartine e T. E. Lawrence. Toda a produção sobre o Oriente estaria alinhada com o objetivo de elaborar o discurso sobre o Outro legitimador da dominação. Alguns anos depois de publicar Orientalismo, Said reforçará esta sua crença na correlação entre escritores e seu tempo ao afirmar que escritores não são "mecanicamente determinados pela ideologia, pela classe ou pela história econômica, mas [...] estão profundamente ligados à história de suas sociedades, moldando e moldados por essa história e suas experiências sociais em diferentes graus." ${ }^{8}$

Segundo Said, dentro do discurso orientalista, cria-se uma determinada imagem dos orientais (sobretudo árabes e muçulmanos): irracionais, crédulos, aduladores, dados a intrigas, à astúcia e à maldade com animais, mentirosos, letárgicos, desconfiados ${ }^{49}$, depravados, infantis ${ }^{50}$, sensuais, imprecisos, propícios ao despotismo, aos subterfúgios e ao atraso ${ }^{51}$, conformistas, vingativos, violentos ${ }^{52}$, desleixados, desorganizados, incapazes de uma "unidade disciplinada e duradoura", de "esforços coletivos" e de cooperar ${ }^{53}$. Mais: os muçulmanos, em parte considerável das obras ocidentais sobre o Oriente, não

\footnotetext{
${ }^{43}$ Ibidem, p. 32.

${ }^{44}$ Ibidem, p. 43-44.

${ }^{45}$ Ibidem, p. 75.

${ }^{46}$ Ibidem, p. 403.

${ }^{47}$ Ibidem, p. 59.

${ }^{48}$ SAID, Edward. Cultura e Imperialismo. São Paulo: Companhia das Letras, 1995, p. 23.

${ }^{49}$ SAID, Edward W. Orientalismo: o Oriente como invenção do Ocidente. São Paulo: Companhia das Letras, 2007, p. 71.

${ }^{50}$ Ibidem, p. 73.

${ }^{51}$ Ibidem, p. 279.

${ }^{52}$ Ibidem, p. 84.

${ }^{53}$ Ibidem, p. 413.
} 


\section{perfil intelectual}

apareceriam sequer como seres humanos ${ }^{54}$.

O orientalismo, como discurso sobre o Outro, tem outra função essencial para Said: se definir em oposição a este Outro. Em outras palavras, definindo um possível Oriente é que um suposto Ocidente constrói sua própria imagem; o Oriente surge assim como uma invenção ocidental, como um espelho no qual o Ocidente se reflete para se inventar e afirmar sua identidade eurocêntrica e discriminatória. 0 medo ao islã (por conta de seu período de hegemonia militar, cultural e religiosa), por exemplo, estaria na base da criação do discurso do islã como símbolo de terror e de devastação, para ser apresentado ao cristão medieval ${ }^{55}$. Maomé teria passado, já a partir daí, a ser apresentado como o disseminador de uma falsa revelação divina, como um representante herético, impostor e imoral de uma religião marcada pela lascívia, pela devassidão, pela sodomia e pela perversão ${ }^{56}$, uma religião miserável, árida e trivial, de uma civilização mística e estacionada ${ }^{57}$ - imagem esta que, segundo Said, atravessou a Idade Média e foi reforçada por autores como Shakespeare, Dante, Cervantes, Roger Bacon e Lutero ${ }^{58}$. 0 islã seria, assim, transformado na "epítome do estranho contra o qual foi fundada toda a civilização europeia, da Idade Média em diante" ${ }^{59}$.

No século XIX, século que havia se iniciado assistindo às teses de que um suposto atraso do Oriente estaria associado à falta de racionalidade ${ }^{60}$ impregnada na cultura da região $0^{61}$, o orientalismo teria ainda assistido a uma aproximação entre língua e raça: não só árabes formariam uma raça inferior, como falaram uma língua inferior, uma língua semítica, em oposição às línguas indo-europeias, "superiores"62

Já no século XX, o orientalismo veria o islã como uma espécie de síntese cultural do Oriente Médio, estudando a política, a sociologia e a economia dos povos islâmicos sempre guardando a religião muçulmana como essência não só predominante, mas também monolítica e imutável de todas as faces possíveis dessas sociedades ${ }^{63}$; algo como, nas palavras de Said, se os orientalistas dissessem: "A história, a política e a economia não têm importância. 0 islã é o islã, o Oriente é o Oriente, e, por favor, levem todas as suas ideias sobre esquerda e a direita, revoluções e mudança de volta para a Disneylândia." ${ }^{64}$ Temos aqui uma

\footnotetext{
${ }^{54}$ Ibidem, p. 133.

${ }^{55}$ Ibidem, p. 97-98

${ }^{56}$ Ibidem, p. 101-106.

${ }^{57}$ Ibidem, p. 282-284.

${ }^{58}$ Ibidem, p. 109-112.

${ }^{59}$ Ibidem, p. 112.

${ }^{60}$ Ideia também presente, segundo Said, em textos mais recentes, como os de Henry Kissinger, que diferencia a Europa pós-newtoniana (e racional) dos povos pré-newtonianos acerca das concepções da realidade (Ibidem, p. 83)

${ }^{61}$ Ibidem, p. 280

${ }^{62}$ Ibidem, p. 148

${ }^{63}$ Ibidem, p. 156.

${ }^{64}$ Ibidem, p. 159.
} 
crítica central de Said a diversos orientalistas, que é a crítica a um aparente essencialismo nos estudos sobre o Oriente, segundo o qual o oriental - e notadamente o muçulmano é dado como fixo e estável ${ }^{65}$, supostamente com determinadas características (não por acaso, características semelhantes às atribuídas ao judeu pelo tradicional antissemitismo europeu: cultuadores do poder, traiçoeiros, arrogantes, gananciosos, impatrióticos... $)^{66}$.

Nessa crítica ao essencialismo orientalista, Said integrará sua crítica à obra de Bernard Lewis num dos maiores embates acerca dos estudos do Oriente Médio. Para Said, Lewis seria um orientalista típico, "imbuído de autoridade", que busca "desprestigiar, diminuir e desacreditar os árabes e o islã" e criar a imagem de um islã potencialmente antissemita, irracional, passional e sem reflexão, com o objetivo de assustar seu público ${ }^{67}$. Gustave Von Gruebaum é outro autor citado por Said, por descrever o islã como "uma entidade cultural que não partilha as nossas aspirações primárias", como uma religião ensimesmada, anti-humanista, sem vigor intelectual, imbuída de impaciência de impedimentos de análise de longo prazo e planejamento na esfera intelectual ${ }^{68}$.

No pós-Segunda Guerra mundial e com as guerras árabe-israelenses, os árabes e muçulmanos passariam, segundo Said, a receber maior atenção no mundo acadêmico, no mundo dos negócios e no mundo dos planejadores de políticas públicas e, ao mesmo tempo - e não por acaso -, a figurar na cultura popular norte-americana. ${ }^{69}$ De uma imagem inicial do árabe nômade em cima de seu camelo e passando pelo "incompetente derrotado" de forma humilhante na guerra de 1967, o árabe passaria, a partir de 1973, a ser desenhado como uma figura ameaçadora e instável que controla o petróleo. Segundo Said, é aí que antissemitismo e o orientalismo mostrariam suas raízes e suas caricaturas em comum: a personificação de determinado grupo étnico como "ameaça ao Ocidente"70.

Nos filmes e na televisão, os árabes seriam caracterizados como libidinosos, desonestos, sanguinários, sádicos, degenerados e portadores da ameaça do jihad. ${ }^{71}$ Em Covering Islam ${ }^{72}$, Said, segundo o qual o islã é mal estudado pelos orientalistas ${ }^{73}$, aprofundará suas teorias de como os especialistas, mas também a mídia, introduzem e difundem uma determinada imagem acerca do resto do mundo, notadamente dos muçulmanos. Um debate interessante acerca dessas representações é possível através

\footnotetext{
${ }^{65}$ Ibidem, p. 411.

${ }^{66}$ Ibidem, p. 408.

${ }^{67}$ Ibidem, p. 421-424.

${ }^{68}$ VON GRUEBAUM, Gustave. Modern Islam: the search for cultural identity. Nova Iorque: Vintage Books, 1964, p. 55, 261 apud SAID, Edward W. Orientalismo: o Oriente como invenção do Ocidente. São Paulo: Companhia das Letras, 2007, p. 396-397

${ }^{69}$ Ibidem, p. 380.

${ }^{70}$ Ibidem, p. 382-383.

${ }^{71}$ Ibidem, p. 383.

${ }^{72}$ SAID, Edward W. Covering Islam: How the Media and the Experts determine how we see the Rest of the World. Nova Iorque: Vintage Books 1997

${ }^{73}$ SAID, Edward W. Orientalismo: o Oriente como invenção do Ocidente. São Paulo: Companhia das Letras, 2007, p. 404-406.
} 


\section{perfil intelectual}

de dois filmes que gostaríamos de trazer para cá. No primeiro deles, Obsession: Radical Islam's War against the West ${ }^{74}$, de 2005, o fundamentalismo islâmico e a "ameaça de jihad" são apresentados como os principais perigos para o Ocidente e os EUA contemporâneos, semelhantes ao que foi o nacional-socialismo hitlerista dos anos 30 e 40. Edward Said não teve a oportunidade de assistir tal filme, lançado dois anos após sua morte, mas ele teria visto nele, certamente, um ótimo exemplo de sua teoria acerca da forma como a mídia desenha o mundo muçulmano (ou pelo menos parte dele) e cria, no Outro, a imagem do perigo irrefreável a ser combatido ou dominado.

Outro documentário, Reel Bad Arabs: how Hollywood vilifies a people ${ }^{75}$, de 2006, inspirado na obra homônima de Jack Shaheen ${ }^{76}$, dá continuidade à perspectiva saidiana de que o cinema norte-americano cria uma imagem negativamente deturpada dos árabes e dos muçulmanos, inclusive de forma semelhante ao que era feito nos períodos áureos do antissemitismo. São incluídos na crítica do referido filme, obras como 0 Corcel Negro (1979), De Volta para o Futuro (1985), Comando Delta (1986), Ishtar (1987), Águia de Aço (1986), True Lies (1994), A Fogueira das Vaidades (1990) e até mesmo o desenho infantil da Disney, Aladdin (1992). É importante ressaltar que o documentário lista outros filmes considerados pelos autores como representações não estereotipadas de árabes e muçulmanos, como Paradise Now (2005), Syriana (2005) e Cruzada (2005).

0 orientalismo possui seus efeitos sobre o próprio Oriente Médio. Segundo Said, a perspectiva orientalista hegemônica fez com que o Oriente Médio tenha deixado de ser um produtor de cultura e mesmo um centro de poder político ${ }^{77}$, se tornando um "satélite intelectual, político e cultural dos Estados Unidos"78, sem possuir "nenhuma revista importante de estudos árabes publicada" e nem "nenhuma instituição educacional árabe capaz de competir com lugares como Oxford, Harvard ou UCLA no estudo do mundo

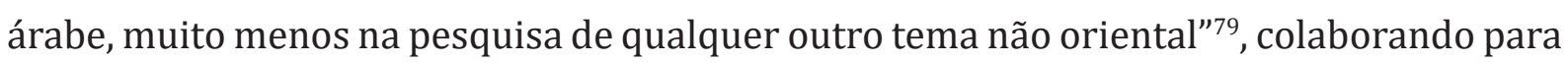
a formação de um sistema de reprodução do discurso orientalista.

Em Cultura e Imperialismo ${ }^{80}$, Said busca traçar um modelo mais geral de relações entre um Ocidente metropolitano, dominador e colonialista e os territórios sob seu domínio, que se estende até os dias de hoje ${ }^{81}$. 0 foco é assim ampliado, deixando as fronteiras do Oriente Médio e do mundo árabe e muçulmano para abraçar analiticamente África,

\footnotetext{
${ }^{74}$ OBSESSION: Radical Islam's War Against the West. Dirigido por Wayne Kopping. Produzido por Peter Mier e Raphael Shore, 2005 (78 min.)

${ }^{75}$ REEL Bad Arabs: How Hollywood Vilifies a People. Direção de Sut Jhally. Produção de Media Education Foundation, 2006. (51 min.)

${ }^{76}$ SHAHEEN, Jack G. Reel Bad Arabs: How Hollywood Vilifies a People. Northampton: Interlink Groups, 2001

77 SAID, Edward W. Orientalismo: o Oriente como invenção do Ocidente. São Paulo: Companhia das Letras, 2007, p. 385.

${ }^{78}$ Ibidem, p. 429.

${ }^{79}$ Ibidem, p. 431.

${ }^{80}$ SAID, Edward W. Cultura e Imperialismo. São Paulo: Companhia das Letras, 1995.

${ }^{81}$ Ibidem, p. 349.
} 


\section{perfil intelectual}

Índia, Austrália, Caribe e Extremo Oriente ${ }^{82}$, onde se repetiriam os vícios essencialistas do orientalismo: a oposição entre "eles" e "nós", o "espírito" de determinado povo (africano, indiano, jamaicano, chinês ou mesmo irlandês), a imagem do Outro misterioso e os argumentos justificadores da dominação em nome da civilização a ser levada a povos bárbaros ${ }^{83}$ e que serve para a autoconstrução, em oposição ao Outro, da ilusória "civilização ocidental".

Aqui, onde Said reafirma suas teorias sobre o discurso sobre o Outro focando na análise das narrativas compartilhadas entre exploradores e ficcionistas, ele buscará ainda estudar o papel das resistências (armada, cultural, nacionalista e associativa, por exemplo), não abordado em Orientalismo ${ }^{84}$. Ao enxergar uma "experiência sobreposta" e uma "interdependência de terrenos culturais, onde colonizador e colonizado coexistiram e combateram um ao outro por meio de projeções, assim como de geografias, narrativas e histórias rivais"85 - como no caso da retroalimentação do imperialismo ocidental e do nacionalismo terceiro-mundista ${ }^{86}$-, Said se aproxima da noção de "zonas de contato" de Mary Louise Pratt ${ }^{87}$, ou seja, de zonas de intercâmbio inevitável entre dominadores e dominados. Para Said, "todas as culturas são mutuamente imbricadas; nenhuma é pura e única, todas são híbridas, heterogêneas, extremamente diferenciadas, sem qualquer monolitismo".88

Nesta obra que representa uma continuidade de Orientalismo, Said tenta demonstrar como outras culturas são tratadas como patologias (com o uso de palavras como "condição", "problema" ou mesmo "síndrome" ${ }^{89}$ ), reafirma sua crítica às essencializações ${ }^{90}$ e ao ensino superior elitizado e especializado (útil a políticas internacionais expansionistas), faz uma defesa do multiculturalismo ${ }^{91}$ e adiciona uma oposição às "tentativas de homogeneização e isolamento de populações em nome do nacionalismo" ${ }^{\prime 22}$. Este último ponto será essencial para a compreensão de seus últimos posicionamentos acerca da questão palestina, que abordaremos agora.

\footnotetext{
${ }^{82}$ Ibidem, p. 11.

${ }^{83}$ Ibidem, p. 11-12.

${ }^{84}$ Ibidem, p. 12-13.

${ }^{85}$ Ibidem, p. 22.

${ }^{86}$ Ibidem, p. 26.

${ }^{87}$ PRATT, Mary Louise. Os Olhos do Império. Relatos de viagem e transculturação. Bauru, EDUSC, 1999; e PRATT, Mary Louise. "Arts of the Contact Zone" in: Profession, 1991, p. 33-40.

${ }^{88}$ SAID, Edward W. Cultura e Imperialismo. São Paulo: Companhia das Letras, 1995, p. 28.

${ }^{89}$ Ibidem, p. 373.

${ }^{90}$ Ibidem, p. 382.

${ }^{91}$ Ibidem, p. 393.

${ }^{92}$ Ibidem, p. 368.
} 


\title{
perfil intelectual
}

\section{A questão palestina}

Nascido em Jerusalém no período do mandato britânico da Palestina e se identificando como um palestino da diáspora, Edward Said foi, certamente, um dos mais proeminentes (e com mais visibilidade midiática) intelectuais palestinos. Dois elementos vistos até este momento terão influência sobre a perspectiva saidiana acerca da assim denominada questão palestina, à qual Said dedicou boa parte de sua pena: por um lado, a percepção do orientalismo como fio condutor de políticas em relação aos árabes e, por outro, a crítica às tentativas de homogeneização em nome do nacionalismo, acompanhada da defesa do multiculturalismo.

No que diz respeito ao primeiro ponto, Said afirma categoricamente que a política do Estado de Israel em relação aos árabes é regida pelo orientalismo mais tradicional ${ }^{93}$, segundo o qual os árabes teriam uma tendência à violência, ao antissemitismo e à incapacidade de separar Estado e religião. Ter-se-ia criado a imagem de que os povos árabes não querem a paz e, mais ainda, são incapazes para viver em paz, são unidos por um gosto pela guerra, pela vingança e pelo objetivo compartilhado de destruir o Estado de Israel ${ }^{94}$.

Por outro lado, a política norte-americana voltada ao Oriente Médio - e à Palestina - também estaria imbuída dos pre(con)ceitos orientalistas, numa:

\begin{abstract}
visão simplificada do mundo em que um grupo relativamente pequeno de civis de elite ligados ao Pentágono formulou para a política dos Estados Unidos em todo o mundo árabe e em todo o mundo islâmico, uma visão em que o terror, a guerra preventiva e a mudança unilateral de regime - sustentados pelo orçamento militar mais polpudo da história - constituem as ideias centrais, debatidas incansável e empobrecedoramente por uma mídia que se arroga o papel de fornecer supostos 'especialistas' que validem a linha geral do governo ${ }^{95}$
\end{abstract}

Acerca do segundo ponto, a recusa do nacionalismo cego e seus riscos consequentes e da negação do Outro foi uma marca das posições de Said acerca da questão palestina. Said se definia como árabe, mas também como internacionalista ${ }^{96}$; além disso, apesar de se identificar como palestino e proclamar ser defensor dos direitos de autodeterminação dos palestinos, não deixava de levar "em consideração a história do povo judeu, o sofrimento e a perseguição de que foi vítima, e o seu próprio direito à autodeterminação"97. Sempre crítico, Said alegava que, por um lado, Israel havia se criado sobre a base da negação da existência do povo palestino e, por outro, o movimento nacional palestino não havia se concentrado em elaborar uma forma de garantir a segurança e a autodeterminação dos judeus sem anular as próprias ${ }^{98}$.

\footnotetext{
${ }^{3}$ SAID, Edward W. Orientalismo: o Oriente como invenção do Ocidente. São Paulo: Companhia das Letras, 2007, p. 409.

${ }^{94}$ Ibidem, p. 410.

${ }^{95}$ Ibidem, p. 23.

${ }^{96}$ CLEMESHA, Arlene. "Uma herança árabe internacionalista”. In: CLEMESHA, A. (org.), op. cit., p. 75.

97 Idem.

${ }^{98}$ Ibidem, p. 76-77.
} 


\section{perfil intelectual}

Sobre os acordos de paz firmados entre autoridades palestinas e israelenses com mediação estadunidense na década de 90, as críticas de Said eram fortes ao ponto de terem culminado com o rompimento com Yasser Arafat após a conclusão do processo de Oslo. Em The End of the Peace Process: Oslo and After ${ }^{99}$, Said discorre sobre seus desacordos em relação aos acordos de Oslo e às posteriores tentativas de negociação entre governo israelense e Autoridade Nacional Palestina; segundo ele, os acordos negaram direitos nacionais e de autodeterminação fundamentais relativos à soberania de um possível Estado palestino, como o controle dos recursos hídricos, a soberania sobre o espaço aéreo, a emissão de documentos e a política monetária e, além disso, não tratavam de assuntos fundamentais como a solução para as colônias judaicas nos territórios palestinos e o fim da ocupação israelense efetiva sobre estes mesmos territórios. Além disso, afirmava Said que "é tolice esperar que um plano de paz que responda aos interesses palestinos saia da cabeça de um político americano"100 e, à época de novas negociações no início dos anos 2000, que

Israel se propõe a reconhecer um Estado palestino - mas provisório e sem território estabelecido. Na essência, tudo que o plano diz é que os palestinos devem abrir mão da resistência, parar de lutar. Em contrapartida, Israel eventualmente levantaria algumas das restrições que impõe ao povo palestino - mas isso é dito sem maiores especificações. 0 plano não prevê mecanismos efetivos de implementação de suas fases. Assim como ocorreu nas negociações de Oslo, em 1993, as decisões ficariam a cargo dos israelenses. Em resumo, estamos falando de um plano que não leva a lugar algum. ${ }^{101}$

Nos seus últimos anos de vida, passou a advogar a criação de um único Estado binacional na Palestina histórica (território que hoje abrange o Estado de Israel e os territórios palestinos), que garantisse os direitos nacionais tanto de judeus quanto de árabes palestinos:

Apesar de a maioria dos palestinos e dos árabes em geral, inclusive os que inicialmente apoiavam a formação de um território compartilhado, defender a ideia de que seriam necessários dois Estados independentes e soberanos para encerrar os enfrentamentos, continuo a acreditar que a única solução para esse conflito é um Estado binacional. [...] Pensar em dois Estados separados é inviável apesar das resistências emocionais e das tentativas de 'provar' a impossibilidade de uma coexistência integrada com direitos iguais e sem discriminações ${ }^{102}$

Para ele, judeus e palestinos compartilhavam "experiências históricas semelhantes [...], marcadas por perseguições" que "possibilitariam a elaboração de um modelo nacional alternativo marcado pelo respeito às diferenças e às similitudes"103. A criação de um único Estado significaria

\footnotetext{
${ }^{99}$ SAID, Edward W. The End of the Peace Process - Oslo and After. Nova Iorque: Vintage Books, 2003.

100 SAID, Edward W. "A Paz não virá” (entrevista) in: Veja, n. 1808, 25 jun. 2003.

${ }^{101}$ Idem.

102 SAID, Edward W. apud FARAH, Paulo Daniel, op. cit., p. 73.

${ }^{103}$ Idem.
} 


\section{perfil intelectual}

o resgate da potencialidade criativa de duas comunidades irmãs em sua origem, inimigas apenas por obra de poderes e interesses que não os seus; [...] o resgate dos seus valores, a valorização de suas heranças, e o fim da reprodução cega do discurso das identidades nacionais. ${ }^{104}$

Apesar do aparente otimismo de Said sobre uma solução de coexistência, ele não imaginava uma Palestina binacional no curto prazo. Teria dito ele que

ainda serão necessárias várias gerações para que palestinos e israelenses consigam chegar a um acordo de paz sensato que garanta uma coexistência entre eles num lugar que não seja um Estado policial e discriminatório com questões eternamente pendentes e animosidades incontroláveis. ${ }^{105}$

Mas ainda que fosse exigido tempo até a construção de um Estado binacional, esta era, para Said, "a única alternativa":

A maioria de nós ainda não aceita a ideia de que os judeus israelenses estão para ficar, que eles não irão embora, da mesma forma que os palestinos também não irão. Isso é, compreensivelmente, muito difícil para os palestinos aceitarem, já que eles estão no processo de perder sua terra e são perseguidos diariamente. Mas com nossa irresponsável e irrefletida afirmação de que os judeus serão forçados a ir embora (como nas Cruzadas), nós não nos concentramos suficientemente no fim da ocupação militar como um imperativo moral, nem em encontrar uma forma de lhes garantir uma segurança e uma autodeterminação que não anulem as nossas. Isso, e não a absurda esperança de que um presidente norte-americano nos daria um Estado, deveria ter sido a base de uma campanha de massa em toda parte. Dois povos em uma terra. Ou igualdade para todos. Ou uma pessoa, um voto. Ou uma humanidade comum afirmada num Estado binacional. ${ }^{106}$

A busca de uma solução multiétnica e multicultural - através do Estado binacional por Said tem parte de suas origens no caso sul-africano, que ele considerava inspirador ${ }^{107}$. Segundo ele, os palestinos deveriam buscar, em Israel, um público de judeus que se engajasse da mesma forma que o Congresso Nacional Africano conquistou um público de brancos sul-africanos que se engajou no combate ao Apartheid, através da formulação de uma pauta de luta que possa emergir como uma luta moral, de "apoio quase universal" e que conquiste "a imaginação do mundo". ${ }^{108}$ Said, entretanto, não tinha perspectiva em assistir essa estratégia adotada pela OLP, por exigir elementos que iam contra a forma de agir da organização: um intenso trabalho e dedicação, uma organização realmente popular e democratizada, o abandono de iniciativas personalistas, o real conhecimento da população norte-americana para conquistá-la ${ }^{109}$.

\footnotetext{
${ }^{104}$ CLEMESHA, A. op. cit., p. 78.

${ }^{105}$ FARAH. P. D. op. cit., p. 73.

${ }^{106}$ SAID, Edward W. "A Única Alternativa” In: Cultura e Política. São Paulo: Boitempo Editorial, 2003, p. 108109.

107 Ibidem, p. 106.

${ }^{108}$ Ibidem, p. 106-107.

109 SAID, Edward W. "Sionismo norte-americano: o verdadeiro problema” In: Cultura e Política. São Paulo: Boitempo Editorial, 2003, p. 92-96.
} 


\section{Debates e críticos}

O caráter polêmico e provocativo das teorias de Edward Said e o tom muitas vezes sarcástico presente em seus escritos conquistaram muitos corações, mas também atraíram diversos críticos.

Said optou por se confrontar intelectual e analiticamente com alguns autores de grande proeminência, sobretudo nos anos 90 . Entre seus calorosos debates, podemos citar os que se firmaram com Samuel Huntington e Bernard Lewis, geralmente com a mesma base para a crítica: segundo Said, ambos tratam os povos, as civilizações e as religiões como "entidades fechadas, lacradas, alheias a qualquer tipo de troca", "monolíticas" enquanto elas seriam, na realidade, interdependentes ${ }^{110}$ e forjadas "na inter-relação e na fertilização mútua"111. As críticas em relação a Lewis costumavam ser mais ácidas, tendo Said referindo-se a ele como um "especialista no Oriente Médio famoso por seu menosprezo pelas pessoas que lá vivem"112, entre outras fórmulas semelhantes.

Mas as críticas a Samuel Huntington também possuíam um caráter combativo. Em um artigo intitulado Choque da Ignorância ${ }^{113}$ (em oposição e clara referência à teoria de Lewis e Huntington de "choque de civilizações"), Said acusa Huntington de desconsiderar a dinâmica e o pluralismo dos grupos humanos, de agir de forma demagógica, de transformar as "civilizações" em identidades monolíticas fechadas, de endossar o paradigma de "Ocidente versus resto" e de construir uma (falsa) teoria que "serve mais para reforçar o auto-orgulho defensivo que para uma compreensão crítica da desconcertante interdependência de nosso tempo"114. Em um prefácio de 2003 a Orientalismo, Said faz referência ao seu debate com Huntington:

Mais do que no choque manufaturado de civilizações, precisamos concentrar-nos no lento trabalho conjunto de culturas que se sobrepõem, tomam isto ou aquilo emprestado uma à outra e vivem juntas de maneira muito mais interessantes do que qualquer modo abreviado ou inautêntico de compreensão poderia supor. ${ }^{115}$

Said não era apenas autor de críticas, mas era (e continua sendo) igualmente alvo de opiniões divergentes sobre sua obra. Acerca de algumas acusações não queremos nos aprofundar, por seu caráter superficial, como a de pequenos grupos minoritários dentro do movimento sionista que chegaram a acusar Said de antissemitismo e nazismo ou dos que se aproveitaram da célebre foto em que ele aparece atirando uma pedra junto a jovens

\footnotetext{
${ }^{110}$ SAID, Edward W. Cultura e Imperialismo. São Paulo: Companhia das Letras, 1995, p. 360.

${ }^{111}$ SAID, Edward W. "A Paz não virá” (entrevista) in: Veja, n. 1808, 25 jun. 2003.

${ }^{112}$ Idem.

${ }^{113}$ SAID, Edward W. "O Choque da Ignorância” In: Cultura e Política. São Paulo: Boitempo Editorial, 2003, p. 42-47.

${ }^{114}$ Idem.

115 SAID, Edward W. Orientalismo: o Oriente como invenção do Ocidente. São Paulo: Companhia das Letras, 2007, p. 23-24.
} 
libaneses e palestinos contra um posto de controle militar israelense abandonado na fronteira entre Líbano e Israel ${ }^{116}$ para tecer diversas acusações que não merecem atenção. Optamos aqui também, por conta das limitações de espaço, por nos ater às críticas às obras ligadas ao Orientalismo de Said, deixando, infelizmente, de lado, seus profícuos debates sobre o conflito israelo-palestino com outros autores ${ }^{117}$.

Queremos, dessa forma, aproveitar este espaço para abordar críticas mais consolidadas que foram tecidas sobre a obra de Edward Said, inclusive de autores elogiados por este em suas obras, como Maxime Rodinson, Albert Hourani e Nikkie Keddie. Martin Kramer ${ }^{118}$, Robert Irwin ${ }^{119}$, Fred Halliday ${ }^{120}$, Ibn Warraq ${ }^{121}$, Keith Windschuttle ${ }^{122}$, Joshua Teitelbaum e Meir Litvak ${ }^{123}$ foram alguns dos autores que buscaram coletar críticas direcionadas a Edward Said, sobretudo a seu clássico, Orientalismo.

Alguns pontos destes autores críticos convergem entre si. 0 primeiro deles talvez interessante de ressaltar é que um bom número deles alega que Said falha ao ignorar, em suas análises, questões econômicas ${ }^{124}$ e subestimar questões culturais ${ }^{125} \mathrm{e}$ religiosas ${ }^{126}$. Outra crítica recorrente é de que Said critica o suposto caráter essencialista dos orientalistas, mas, ele mesmo, faria uma crítica essencialista ao Ocidente, englobando autores diferentes demais para serem reunidos numa mesma análise e criando uma espécie de "ocidentalismo" homogêneo e caricatural ${ }^{127}$, enquanto, na realidade, as percepções sobre árabes e muçulmanos seriam diversas ${ }^{128}$. Uma terceira crítica repetida por diversos autores é a de que Said ignora estudos orientalistas que não sejam ingleses, franceses e norte-americanos; faltariam análises sobre o orientalismo alemão ${ }^{129}$, russo ${ }^{130}$

\footnotetext{
${ }^{116}$ Imagem disponível em: <http://www.faithfreedom.org/oped/said_stone.jpg> Acesso em 15 ago. 2015.

${ }^{117}$ Robert Irwin, por exemplo, faz prova de seu sarcasmo direcionado a Said não apenas sobre sua análise sobre os estudos orientalistas, mas também à sua proposta de Estado binacional, que ele considera "ter o mesmo grau de exequibilidade política" que os "planos para a criação do Reino de Shangri-lá" (IRWIN, Robert. Pelo Amor ao Saber: os Orientalistas e seus Inimigos. Rio de Janeiro: Editora Record, 2006, p. 358-359)

118 KRAMER, Martin. "Said's Splash" in: Ivory Towers on Sand. Disponível em: < http://www.oocities.org/ martinkramerorg/SaidSplash.htm>. Acesso em 15 ago. 2015

${ }^{119}$ IRWIN, Robert. op. cit.

${ }^{120}$ HALLIDAY, Fred. “'Orientalism' and its critics” in: British Journal of Middle Eastern Studies, v. 20, n. 2, 1993, p. 145-163.

${ }^{121}$ WARRAQ Ibn. Debunking Edward Said, 30 mai. 2003. Disponível em: <http://www.butterfliesandwheels. org/2003/debunking-edward-said/>. Acesso em: 15 ago. 2015

122 WINDSCHUTTLE, Keith. “Edward Said's Orientalism revisited” in: Quadrant, jan./fev. 2000.

123 TEITELBAUM, J.; LITVAK, M., op. cit.

${ }^{124}$ HALLIDAY, F., op. cit., p. 150.

${ }^{125}$ WARRAQ. A., op. cit.

${ }^{126}$ IRWIN, R., op. cit., p. 342; TEITELBAUM, J; LITVAK, M., op. cit.

${ }^{127}$ KRAMER, M., op. cit.

${ }^{128}$ Idem.

${ }^{129}$ HOURANI, Albert apud KRAMER, M., op. cit.

${ }^{130}$ IRWIN, R., op. cit., p. 334.
} 


\section{perfil intelectual}

e húngaro ${ }^{131}$ ou sobre estudos sobre persas e turcos ${ }^{132}$, além das contribuições acadêmicas dos próprios autores árabes ${ }^{133}$. Alguns críticos de Said dirão ainda que a obra de Said atraiu e deu escopo intelectual para o fundamentalismo religioso ${ }^{134}$.

Bernard Lewis, criticado aberta e insistentemente por Said ao longo do tempo, afirma que este distorceu a história dos estudos do Oriente. Maxime Rodinson (por outro lado, elogiado por ele) declarou que Said se deixou levar por sua própria militância, o que o levou a fazer "declarações excessivas", opinião compartilhada por Albert Hourani, que ainda afirma que Said distorceu o termo "orientalismo", deslegitimando toda uma área de estudos. Nikkie Keddie, também elogiado por Said, enxergou na obra deste consequências ruins, por sua análise ser usada para deslegitimar de forma seletiva autores e estudos. Rodinson, numa perspectiva semelhante, chega a comparar a análise saidiana dos estudos orientalistas a uma espécie de stalinismo intelectual, opinião próxima à de P. J. Vatikiotis, que viu a implantação de um quase macarthismo nos estudos do Oriente Médio por parte de Said ${ }^{135}$, cuja obra teria estimulado a demonização dos que fossem acusados de orientalistas.

William Montgomery Watt e Clive Dewey fazem críticas ainda mais duras: afirmam, respectivamente, que Said simplesmente não conhece o islã e que Orientalismo é um livro "tecnicamente ruim", no que diz respeito às fontes, conclusões, rigor científico e equilíbrio, criando uma caricatura do Ocidente com objetivos políticos ${ }^{136}$.

Martin Kramer faz suas próprias críticas à obra de Said: afirma que o autor de Orientalismo teria se aproveitado de uma "onda" foucaultiana e do terceiro-mundismo sedento de um manifesto político-intelectual para publicar suas teorias com sucesso, apesar de uma suposta superficialidade e seletividade de sua pesquisa. Kramer alega ainda que Orientalismo apresenta uma análise "superficial e preguiçosa", carece de provas para suas afirmações (como a rede de interesses que ligaria governos, corporações, militares e acadêmicos) e serviu de argumento para tentar favorecer o acesso aos postos acadêmicos por parte de pesquisadores árabes, muçulmanos e descendentes que teriam, pela ótica saidiana, um "conhecimento privilegiado" sobre os assuntos do Oriente Médio. Kramer ainda põe em dúvida o próprio caráter de Said, alegando ser este desonesto por se dizer entre dois mundos, enquanto seria, na verdade, "a quintessência do insider institucional" e um constante autor de autovitimização. ${ }^{137}$

Robert Irwin tece críticas igualmente pouco elogiosas à obra de Said. Irwin define Orientalismo não como "uma história dos estudos orientais, mas uma polêmica altamente

\footnotetext{
${ }^{131}$ TEITELBAUM, J; LITVAK, M., op. cit.

132 IRWIN, R., op. cit., p. 328.

${ }^{133}$ IRWIN, R., op, cit., p. 340.

${ }^{134}$ WINDSCHUTTLE, K., op. cit.

${ }^{135}$ KRAMER, M. op. cit.

${ }^{136}$ Idem.

${ }^{137}$ Idem.
} 


\section{perfil intelectual}

seletiva sobre certos aspectos da relação entre o conhecimento e o poder"138, "obscura"139, "fantasiosa" e de "valor duvidoso"140, aparentemente, "escrito às pressas", "repetitivo" e com "muitos erros factuais" e que demonstra uma "ignorância espantosa da história do Oriente Médio"141 e uma "argumentação incoerente"142. Segundo Irwin, o legado efetivo do "mundo da fantasia de Said"143 representado em Orientalismo seria a calúnia feita a gerações de acadêmicos sérios e comprometidos com o conhecimento ${ }^{144}$, já que seus principais objetivos não teriam sido alcançados: nem os orientalistas teriam mudado suas práticas de trabalho e nem os imperialistas teriam se importado com suas críticas ${ }^{145}$.

Para Irwin, Orientalismo possui, no máximo, "qualidades de um bom romance"146 ("Ele é emocionante, está repleto de vilões sinistros, bem como de um número bastante menor de mocinhos, e o quadro que ele apresenta do mundo provém de uma rica imaginação, mas em sua essência é ficcional"147) e o fato de um livro, segundo ele, escrito de má fé ${ }^{148}$, ter sido levado a sério seria um "escândalo e um desdouro para a qualidade da vida intelectual na Grã-Bretanha"149. Buscando as causas do sucesso do livro, Irwin afirma enxergar apenas possibilidades como antissionismo, antiamericanismo e a combinação dentro da obra de elementos então na moda na época de sua lançamento, como as teorias foucaultianas, gramscianas e pós-modernas questionadoras da objetividade ${ }^{150}$.

Joshua Teitelbaum e Meir Litvak, num tom conservador, fazem uma crítica à "doutrina sagrada" em que foi transformada a perspectiva saidiana. Para isso, retomam alguns dos argumentos já aqui citados, mas também o posicionamento de Sadiq Jalal al-Azm, segundo o qual Said teria um posicionamento anti-intelectualista, por buscar impor limites à produção intelectual. Além disso, atacam o que chamam de "politização dos estudos" sobre o Oriente Médio em decorrência da obra de Said e questionam a total refutação de generalizações por parte dele: afinal, a sociologia e os estudos da cultura seriam possíveis sem algum grau de generalização ${ }^{151}$

Outro opositor firme da análise saidiana é o paquistanês e crítico do islã, Ibn Warraq, segundo o qual Orientalismo - uma obra, segundo ele, repleta de "frases sem sentido" e de

\footnotetext{
${ }^{138}$ IRWIN, R., op. cit., p. 328.

${ }^{139}$ Ibidem, p. 336.

${ }^{140}$ Ibidem, p. 331.

${ }^{141}$ Ibidem, p. 329.

${ }^{142}$ Ibidem, p. 331.

${ }^{143}$ Ibidem, p. 346.

${ }^{144}$ Ibidem, p. 343.

${ }^{145}$ Ibidem, p. 349.

${ }^{146}$ Ibidem, p. 359.

${ }^{147}$ Idem.

${ }^{148}$ Idem.

${ }^{149}$ Idem.

${ }^{150}$ Idem.

${ }^{151}$ TEITELBAUM, J; LITVAK, M., op. cit.
} 


\section{perfil intelectual}

"contradições" - representou uma forma de "terrorismo intelectual", que teria calado tanto os estudos sobre o islã quanto a autocrítica dos próprios árabes e muçulmanos. Warraq vai além e diz que Said não tinha sequer competência para escrever o que pretendia, preenchendo suas obras com excessiva vitimização, autopiedade e antiocidentalismo ${ }^{152}$.

0 australiano Keith Windschuttle também publica uma dura contestação ao Orientalismo de Said. Segundo Windschuttle, a aproximação do imperialismo com os estudos orientais feita por Said não pode sequer "ser levada a sério", seja por questões metodológicas (segundo o autor, as ideias de Malek e Foucault, combinadas por Said seriam, na realidade, incompatíveis), seja pelo caráter supostamente essencialista e aistórico $^{153}$ da análise saidiana ${ }^{154}$.

Uma última crítica importante feita a Said e que gostaríamos de explicitar aqui é a de Fred Halliday, autor irlandês e membro da New Left Review. Embora Halliday concorde com o pressuposto saidiano de que os estudos sobre o Oriente Médio devem objetivar o desmonte de preconceitos e estereótipos, ele não poupa Said de críticas, seja contestando o próprio uso dos termos "orientalismo" (que, por atravessar épocas e gêneros de expressão de forma tão livre, acabaria por ter seu valor analítico e explicativo esvaziado ${ }^{155}$ ) e "Oriente"156, seja pela oposição à crença de que as ideias produzidas sob um contexto de dominação ou em favor dela não sejam válidas ${ }^{157}$ e pela ausência de uma análise das ideias e ideologias do Oriente Médio ${ }^{158}$.

Antes de partirmos para nossas conclusões, é preciso ressaltar que o próprio Said reconhece e rebate parte dessas críticas. Em seu anúncio sobre a metodologia em Orientalismo, Said deixa claro que focará na análise de material britânico, francês e estadunidense e que o livro "está longe de ser uma história completa ou relato geral do Orientalismo". Completa ele: "dessa deficiência estou muito consciente"159. Em Cultura e Imperialismo, está presente também o reconhecimento da ausência de análises sobre os impérios austro-húngaro, russo, espanhol, português e mesmo otomano ${ }^{160}$.

Nesta mesma obra, Said aborda, ainda que rapidamente, duas importantes ideologias do Oriente Médio: o nacionalismo e o islamismo. Retomando a ideia de Franz Fanon dos riscos de uma "consciência nacional despreparada", Said faz também um ataque à "alternativa

\footnotetext{
${ }^{152}$ WARRAQ, I., op. cit.

${ }^{153}$ Windschuttle irá mesmo afirmar que a "inapta manipulação de material histórico" não corrigida por Said demonstraria que este "não tem admiradores conhecedores de história".

${ }^{154}$ WINDSCHUTTLE, K., op. cit.

${ }^{155}$ HALLIDAY, F., op. cit., p. 158.

${ }^{156}$ Idem.

${ }^{157}$ Ibidem, p. 159-160.

${ }^{158}$ Ibidem, p. 161.

159 SAID, Edward W. Orientalismo: o Oriente como invenção do Ocidente. São Paulo: Companhia das Letras, 2007, p. 47-55.

${ }^{160}$ SAID, Edward W. Cultura e Imperialismo. São Paulo: Companhia das Letras, 1995, p. 24.
} 
teocrática", reflexo, segundo ele, de uma "consciência religiosa despreparada"161.

Said também possui uma resposta aos que acreditam que sua obra é responsável por uma espécie de "filtro étnico" e moral para os estudos sobre o Oriente Médio. Já no texto original de 1978 de Orientalismo, Said afirma não acreditar "em absoluto na proposição limitada de que apenas um negro pode escrever sobre negros, um muçulmano sobre muçulmanos, e assim por diante"162. Quanto à ideia de que sua obra criou uma espécie de Ocidente caricaturizado e essencializado, Said afirma, em sua último parágrafo de Orientalismo que a "resposta ao Orientalismo não é um Ocidentalismo"163.

No seu posfácio ao Orientalismo, escrito em 1994 e publicado pela primeira vez em 1995, Said tem a oportunidade de responder a outras críticas acima expostas. Segundo Said, seu livro não foi pautado numa perspectiva antiocidental generalizante, não buscou desenhar o Ocidente como uniformemente contrário ao islã e aos "orientais" ou o islã como uma religião perfeita e nem apoiar o islamismo: para ele, ao contrário, não há nenhuma realidade estável e seu livro se apresenta como uma obra antiessencialista ${ }^{164}$, que reconhece a realidade humana como algo sendo constantemente feito e desfeito ${ }^{165} \mathrm{e}$ que faz uma "crítica multicultural do poder que usa o conhecimento para se promover"166 - mas que, reconhece, talvez tenha sido mal compreendida ${ }^{167}$.

Neste mesmo posfácio, Said dialoga com Hourani, recebendo sua crítica de forma positiva (afirmando, inclusive que o orientalismo não é "mau, desleixado ou sempre o mesmo", possuindo numerosas realizações eruditas e humanísticas ${ }^{168}$ ), e reconhece abertamente o caráter político e engajado de sua obra, definindo Orientalismo não como "uma máquina teórica", mas como "um livro que toma partido"169.

Finalmente, Edward Said afirma que, com Orientalismo, ele "queria que os leitores usassem [sua] obra para poder produzir novos estudos, que iluminariam a experiência histórica dos árabes e outros de modo generoso e transformador"170 e para "repensar e reformular as experiências históricas outrora baseadas na separação geográfica dos povos e das culturas"171.

\footnotetext{
${ }^{161}$ Ibidem, p. 377.

${ }^{162}$ SAID, Edward W. Orientalismo: o Oriente como invenção do Ocidente. São Paulo: Companhia das Letras, 2007, p. 429.

163 Ibidem, p. 437.

${ }^{164}$ Ibidem, p. 440.

165 Ibidem, p. 443.

166 Ibidem, p. 446.

167 Idem.

${ }^{168}$ Ibidem, p. 452-453

${ }^{169}$ Ibidem, p. 451.

170 Ibidem, p. 450.

171 Ibidem, p. 466.
} 


\section{perfil intelectual}

\section{Conclusões}

A partir do que foi até aqui exposto, acreditamos que algumas conclusões se fazem necessárias. Em primeiro lugar, pudemos compreender a perspectiva saidiana acerca do orientalismo. Segundo esta, o orientalismo seria, ao mesmo, tempo, uma tradição acadêmica influente, mas também uma doutrina política, uma "área de interesse definida por viajantes, empresas comerciais, governos, expedições militares, leitores de romances e de relatos de aventuras exóticas, historiadores naturais e peregrinos" e um "sistema de verdades" - sob a ótica nietzschiana, segundo a qual as verdades não passam de ilusões. ${ }^{172}$ 0 orientalismo aparece, assim, como um estilo de pensamento sobre o Oriente que teria permitido ao Ocidente subordiná-lo a sua dominação, traçando fronteiras hierárquicas fronteiras, de modo a idealizar o Oriente e forjar uma identidade cultural europeia. 0 Oriente surgiria então como uma totalidade homogênea criada artificialmente onde há uma enorme diversidade, com a função político-ideológica de ocultar a existência do Outro e torna-lo ao mesmo tempo exótico, condenável, inferior e dominável, através de um envolvimento institucional que disfarçaria de conhecimento as ideologias que interessam a um poder imperialista.

Em segundo lugar, cabe a nós ressaltar que o alcance da obra de Said não se limitou ao campo de origem acadêmica de seu autor - a crítica literária - e transbordou suas fronteiras em direção aos estudos da cultura, da geografia humana e da história, entre outras áreas do conhecimento, modificando a forma de fazer pesquisa sobre árabes, sobre o mundo muçulmano e sobre o mundo "não-ocidental" de uma forma geral. Este ponto contraria os críticos de Said que afirmam que seu objetivo de mudar a forma de produzir o conhecimento acerca do Oriente Médio, dos árabes e do islã não teria sido alcançado.

Em terceiro lugar, acerca do engajamento de Edward Said na questão palestina, talvez a ideia mais representativa de seu pensamento é a que ele expressava ao pregar que os palestinos deveriam conquistar a imaginação dos próprios palestinos, mas também dos demais povos, inclusive de seus opressores.

Em quarto lugar, em relação às críticas feitas à obra de Said - provavelmente o teor mais delicado deste breve estudo -, talvez nossas conclusões devam se basear na ideia de que as críticas postuladas não devem ser apenas endossadas pelos opositores dos pressupostos expostos por Said; pelo contrário, elas devem ser consideradas pelos próprios acadêmicos e intelectuais influenciados por sua obra, de modo a repensá-la e aprimorá-la sem romper com esta ou abandonar o cerne de seu conteúdo analítico. Embora muitas das críticas tenham validade, elas não parecem abalar o centro do debate proposto pela extensa obra deste autor.

Para concluir nosso texto, gostaríamos de retomar uma última fala de Edward Said, desta vez uma de suas memórias, mas que reflete bem este nosso último ponto: "com ${ }^{172}$ Idem, p. 276-277 


\section{perfil intelectual}

tantas dissonâncias em minha vida, de fato aprendi a preferir estar fora do lugar e não absolutamente certo"173.

\section{Referências bibliográficas}

CLEMESHA, Arlene (org.). Edward Said: Trabalho intelectual e crítica social. São Paulo: Editora Casa Amarela, 2005.

COLUMBIA University. Remembering Edward W. Said: November 1, 1935 - September 25, 2003. Nova Iorque: Columbia University, 2004.

HALLIDAY, Fred. “'Orientalism' and its critics” in: British Journal of Middle Eastern Studies, v. 20 , n. 2,1993 , p. $145-163$.

IRWIN, Robert. Pelo Amor ao Saber: os Orientalistas e seus Inimigos. Rio de Janeiro: Editora Record, 2006.

JASANOFF, Maysa. "Before and after Said" in London Review of Books, v. 28, n. 11, 8 jun. 2006.

KRAMER, Martin. "Said's Splash” in: Ivory Towers on Sand. Disponível em: <http://www. oocities.org/martinkramerorg/SaidSplash.htm>. Acesso em: 15 ago. 2015.

OBSESSION: Radical Islam's War Against the West. Dirigido por Wayne Kopping. Produzido por Peter Mier e Raphael Shore, 2005 (78 min.).

PRATT, Mary Louise. Os Olhos do Império. Relatos de viagem e transculturação. Bauru, EDUSC, 1999.

. Arts of the Contact Zone, in: Profession, 1991, p. 33-40.

REEL Bad Arabs: How Hollywood Vilifies a People. Direção de Sut Jhally. Produção de Media Education Foundation, 2006 (51 min.).

SAID, Edward W. Covering Islam: How the Media and the Experts determine how we see the Rest of the World. Nova Iorque: Vintage Books 1997.

. Cultura e Imperialismo. São Paulo: Companhia das Letras, 1995.

. Cultura e Política. São Paulo: Boitempo Editorial, 2003.

Fora do Lugar: Memórias. São Paulo: Companhia das Letras, 2004.

. Orientalismo: o Oriente como invenção do Ocidente. São Paulo: Companhia das Letras, 2007.

${ }^{173}$ SAID, Edward W. Fora do Lugar: Memórias. São Paulo: Companhia das Letras, 2004, p. 429. 
perfil intelectual

. Reflexões sobre o exílio e outros ensaios. São Paulo: Companhia das Letras, 2003.

. Representations of the Intellectual. Nova Iorque: Vintage Books, 1996.

. The End of the Peace Process - Oslo and After. Nova Iorque: Vintage Books, 2003.

. The Question of Palestine. Nova Iorque: Vintage Books, 1992.

. "A Paz não virá” (entrevista) in: Veja, n. 1808, 25 jun. 2003.

. "Between Worlds" in: London Review of Book, n. 9, v. 20, pp. 3-7, mai. 1998.

SHAHEEN, Jack G. Reel Bad Arabs: How Hollywood Vilifies a People. Northampton: Interlink Groups, 2001.

SPRINKER, Michael (ed.). Edward Said: a Critical Reader. Cambridge: Blackwell Publishers, 1992.

TEITELBAUM, Joshua; LITVAK, Meir. "Students, teachers, and Edward Said: taking stock of Orientalism” in: The Middle East Review of International Affairs, v. 10, n. 2, mar. 2006.

WARRAQ Ibn. Debunking Edward Said, 30 mai. 2003. Disponível em: <http://www.butterfliesandwheels.org/2003/debunking-edward-said/>. Acesso em 14 ago. 2015

WINDSCHUTTLE, Keith. “Edward Said's Orientalism revisited” in: Quadrant, jan./fev. 2000. 